University of Nebraska - Lincoln

DigitalCommons@University of Nebraska - Lincoln

Publications from USDA-ARS / UNL Faculty

U.S. Department of Agriculture: Agricultural

Research Service, Lincoln, Nebraska

2013

Characterization of white mold disease avoidance in common bean

Phillip N. Miklas

USDA-ARS, phil.miklas@ars.usda.gov

Lyndon D. Porter

USDA-ARS

James D. Kelly

Soil and Microbial Sciences

James R. Myers

Oregon State University, james.myers@oregonstate.edu

Follow this and additional works at: https://digitalcommons.unl.edu/usdaarsfacpub

Miklas, Phillip N.; Porter, Lyndon D.; Kelly, James D.; and Myers, James R., "Characterization of white mold disease avoidance in common bean" (2013). Publications from USDA-ARS / UNL Faculty. 1282.

https://digitalcommons.unl.edu/usdaarsfacpub/1282

This Article is brought to you for free and open access by the U.S. Department of Agriculture: Agricultural Research Service, Lincoln, Nebraska at DigitalCommons@University of Nebraska - Lincoln. It has been accepted for inclusion in Publications from USDA-ARS / UNL Faculty by an authorized administrator of DigitalCommons@University of Nebraska - Lincoln. 


\title{
Characterization of white mold disease avoidance in common bean
}

\author{
Phillip N. Miklas • Lyndon D. Porter • \\ James D. Kelly • James R. Myers
}

This article is a U.S. government work, and is not subject to copyright in the United States.

Accepted: 12 December 2012 / Published online: 8 January 2013

(C) US Government 2013

\begin{abstract}
White mold, caused by Sclerotinia sclerotiorum, is a devastating fungal disease of common bean (Phaseolus vulgaris L.) worldwide. Physiological resistance and disease avoidance conferred by plant architecture-related traits contribute to white mold field resistance. Our objective was to further examine white mold disease avoidance in common bean. A comparative map composed of 79 quantitative trait loci (QTL) for white mold resistance (27), disease avoidance traits (36) and root traits (16) was generated. Thirteen white mold resistance QTL, six with strong and seven with weak associations with disease avoidance traits, were observed. Root length and lodging QTL co-located in three regions. Canopy porosity and height, and lodging were highly correlated with disease severity score in field screening trials conducted from 2000 to 2011. Resistance to lodging was extremely important for reducing disease severity in both dry and snap bean $(r=$ 0.61 across 11 trials). Avoidance traits were less
\end{abstract}

P. N. Miklas $(\bowtie) \cdot$ L. D. Porter

Vegetable and Forage Crop Research Unit, USDA-ARS, 24106 N. Bunn Rd,

Prosser, WA 99350, USA

e-mail: phil.miklas@ars.usda.gov

J. D. Kelly

Department of Plant, Soil and Microbial Sciences,

East Lansing, MI, USA

J. R. Myers

Department of Horticulture, Oregon State University, Corvallis, OR, USA effective in reducing disease severity in trials with heavy disease pressure. Dry bean lines with physiological resistance in combination with disease avoidance traits did not require fungicide application to protect yield potential under moderate and heavy disease pressure. Given the complexity of disease resistance as evidenced by the comparative QTL map, marker-assisted breeding for disease avoidance is not recommended at this time. Instead, selecting for resistance to white mold in the field, in combination with high yield potential and acceptable maturity, is the recommended strategy for improving both disease avoidance and physiological resistance to white mold in cultivars with commercially acceptable agronomic traits.

Keywords Dry bean · Lodging · Microclimate · Phaseolus vulgaris $\cdot$ Sclerotinia sclerotiorum . Snap bean

\section{Introduction}

White mold of common bean (Phaseolus vulgaris L.) caused by the fungal pathogen, Sclerotinia sclerotiorum Lib. de Bary, is a devastating disease that limits yield potential (Del Río et al. 2004; Singh and Schwartz 2010) and reduces seed and pod quality. The disease is widespread, occurring across major bean production regions of North and South America, and Europe (Schwartz and Steadman 1989). Epidemics also occur in Australia (Jones et al. 2011), and in some African and 
Asian countries (Allen 1983). Epidemics are favoured by moderate temperatures $\left(18-23{ }^{\circ} \mathrm{C}\right)$ and moist conditions, thus are most frequent in temperate zones, or at higher elevations in humid sub-tropical regions (Schwartz and Steadman 1989). Sclerotinia sclerotiorum is pathogenic on more than 450 plant species (Purdy 1979; Boland and Hall 1994), including many important crops (alfalfa, canola, carrots, lettuce, potato, soybean, sunflower, and others).

The pathogen forms sclerotia on and within infected bean tissues toward the end of the disease cycle. These hardened-dense mycelial bodies can remain in the soil for years awaiting the right conditions for germination (Schwartz and Steadman 1989). This persistence of inocula in the soil in combination with wide host range contributes to high epidemic disease potential for most production fields where susceptible crops are grown. Infection in most crops, including common bean, is by ascospores which primarily land on senescent blossoms but also colonize other dead or dying tissues (leaves, cotyledons) of the host plant. The ascospores use the senescent blossoms or dead tissue as a nutrient source for germination and subsequent growth of an appressorium which is then used to penetrate the epidermis and initiate infection within the bean plant. The only known host crop that can be infected by mycelium invasion of roots, sunflower, results from the mycelial germination of the sclerotia buried in the soil.

The carpogenic germination of apothecia from sclerotia, the germination of ascospores, and severity of infection within host tissue is influenced by moisture and temperature (Schwartz and Steadman 1978, 1989; Phillips 1994; Harikrishnan and Del Río 2006). To germinate apothecia, sclerotia require moist soil conditions for 1 to 2 weeks, and cool temperatures from 11 to $20{ }^{\circ} \mathrm{C}$ (Schwartz and Steadman 1989). Mycelia of infected tissues grow most rapidly under moist conditions and at moderate temperatures of $20-25^{\circ} \mathrm{C}$. These optimum conditions for fungal germination and plant infection coincide with canopy closure of the bean crop which occurs during flowering growth stages (R1-R3), about 50 days after planting. Thus, both microclimate within the crop canopy and climatic conditions in general, have a major impact on white mold epidemics.

Microclimate within the bean canopy can be modified by cultural practices (row spacing, plant population density, number and timing of irrigation applications, $\mathrm{N}$-fertilizer) and plant architecture (tall upright plants, reduced branching, porous canopy, reduced lodging), to be less favourable for the pathogen. Increasing row spacing from $19 \mathrm{~cm}$ to $75 \mathrm{~cm}$ in snap bean reduced disease severity by 25 to $41 \%$ without compromising yield (Peachey et al. 2006). Maintaining equal row spacing but reducing in-row plant densities from 15 to 5 plants/m (Vieira et al. 2010) or from 12 to 6 plants $/ \mathrm{m}$ (Paula Júnior et al. 2009) diminished white mold and increased yield. Weiss et al. (1980) noted a 13-fold increase in disease incidence for great northern bean under heavily irrigated plots. Added nitrogen increased white mold incidence in on-farm trials in Nebraska (Nuland et al. 1989). Moreover, added nitrogen often does not contribute significantly to increased yield in dry bean (Eckert et al. 2011). It is clear from afore-mentioned studies that cultural practices can be used to create less dense crop canopies with less favourable microclimates for white mold epidemics. These same practices, however, can reduce yield potential to unacceptable levels in the absence of white mold pressure, so a delicate balancing act often ensues to maintain yield potential while minimizing risk from disease by cultural means.

Plant architecture effects on plant canopy and white mold epidemics in common bean was recently reviewed by Ando et al. (2007). Early studies from University of Nebraska researchers showed that more upright genotypes were less susceptible than genotypes with prostrate growth habits (Schwartz et al. 1978, 1987). In addition, prostrate growth habit with a more porous canopy, or which formed a tunnel over the closed furrow, such as 'Aurora' small white bean, had less disease develop, and was less prone to white mold, even under heavy irrigation (Blad et al. 1978). Conversely, for the great northern 'Tara' with prostrate growth habit and dense leaf canopy, white mold severity increased from 18 to $50 \%$ for the high rate of irrigation.

Kelly (2001) reviewed the modification of plant growth habit in common bean to improve adaptation and yield. He gave a historical perspective of the development of the Type I bush determinant growth habit (see Singh 1982, for key to growth habit types) in snap bean to promote mechanical harvest and in navy bean to promote production in humid climates. Although, the bush navy beans provided an upright growth habit, they were still prone to white mold epidemics, in part, because of compact growth and more prolific branching (Schwartz et al. 1978; Miklas and Grafton 1992) and lack of physiological resistance. Beans with Type II indeterminate short-vine growth habit also exhibit upright architecture but with less compact branching and a 
narrower overall plant profile (Kolkman and Kelly 2002). The trend since 1980 has been the integration of the Type II growth habit into small ( $\sim 20 \mathrm{~g} 100$

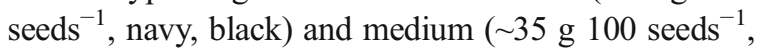
pinto, great northern, small red and pink) seed-sized market classes. The Type II indeterminacy provides wider adaptation to stresses, and the upright architecture enables direct harvesting (Eckert et al. 2011), and has the added benefit of contributing to white mold avoidance (Schwartz et al. 1987). For the medium seed-size market classes (pinto, great northern, pink, etc.), Type II beans inherently exhibit less yield potential than prostrate Type III indeterminate vine growth habits. The yield gap has narrowed considerably, however, as evidenced by the performance of the new upright pinto bean cultivars 'Stampede' and 'Lariat' (Osorno et al. 2010) in national yield trials (Miklas 2010). Some of these high yielding new upright Type II beans have greater plant biomass which can create dense canopies with less capacity for disease avoidance.

Andean beans have inherently less yield potential than Middle American beans which may contribute to white mold avoidance. Type I bush beans in the large seed-sized market classes from the Andean gene pool, have better disease avoidance due to a more upright architecture and porous canopy which supports fewer pods and subsequently generates fewer senescing blossoms compared to their Type I Middle American navy bean counterparts. Perhaps genetic control of the Type I bush habit by different genes (Kolkman and Kelly 2003; Kwak et al. 2008); the fin locus on chromosome 1 in the Andean gene pool versus an unknown gene on chromosome 7 derived by X-ray mutation for the Middle American gene pool, contributes to this difference in response. Furthermore, there is an overall recognition that many Andean genotypes appear to possess partial physiological resistance (Soule et al. 2011).

In addition to cultural practices and disease avoidance traits, partial physiological resistance of the host and fungicide applications (Steadman 1979) contribute to integrated management strategies for control of white mold disease in common bean. The expression of avoidance and physiological resistance mechanisms in the common bean host are often confounded under field conditions making it difficult to discern the contribution of one mechanism from the other. Greenhouse (Petzoldt and Dickson 1996; Terán et al. 2006) and other ex situ screening methods (Kolkman and Kelly 2000; Miklas et al. 1992) have been developed to evaluate partial physiological resistance in the absence of avoidance, but no tests exist to evaluate avoidance in the absence of physiological resistance.

New DNA marker technologies and genetic mapping populations have enabled discovery of genomic regions possessing gene(s) or QTL with partial effect on resistance to white mold (Soule et al. 2011). The goal for breeders is to identify those QTL with major effect and stable expression across environments and genetic backgrounds. Although, recent studies emphasize characterization and breeding for physiological resistance (Terán and Singh 2009, 2010; Pérez-Vega et al. 2012), some QTL involved in field resistance to white mold (avoidance and physiological) have been associated with plant architectural traits which confer disease avoidance (Miklas et al. 2001; Park et al. 2001; Kolkman and Kelly 2003; Soule et al. 2011). The co-localization of QTL conditioning field resistance and avoidance traits support earlier inheritance studies (Park 1993; Miklas and Grafton 1992; Kolkman and Kelly 2002) which showed an influence of agronomic traits on white mold response in the field. Further examination of identified QTL for association with white mold avoidance traits may contribute to a better understanding of the inheritance of resistance and facilitate the breeding of cultivars with improved field resistance to white mold.

Our goal is to review and investigate field control of white mold in common bean with emphasis on disease avoidance traits. Secondly, the interaction of avoidance and physiological resistance on efficacy of fungicide treatment will be examined.

\section{Materials and methods}

A comparative genetic map of QTL affecting white mold resistance and avoidance traits was constructed from previously published results. Basically, the comparative map for white mold resistance QTL in common bean developed by Soule et al. (2011) was updated herein to include the new QTL identified by Mkwaila et al. (2011) and Pérez-Vega et al. (2012), and all the QTL conditioning avoidance traits from the studies reviewed by Soule et al. (2011). In addition, QTL associated with plant internode length (IL), plant height (HT), branch angle (AG), lodging (LDG) and root traits (length, density, surface area) from studies unrelated to white mold (Tar'an et al. 2002; Beebe et 
al. 2006; Checa and Blair 2008; Cichy et al. 2009), were added to the map. The QTL were integrated by comparing markers in common among the different genetic maps.

Phenotypic association of agronomic traits and white mold disease severity in common bean was examined across disease screening field trials conducted from 2000 to 2011 in Washington, Oregon, and Michigan. For the Washington trials conducted at the USDA-ARS, Cropping Systems Research Farm at Paterson, WA, in 2000 and 2001, data for canopy traits, porosity (1 to 5) and height (cm), were associated with disease score (1 to 9). The canopy porosity score is fully described by Park et al. (2001) and presented briefly here: $1=$ an open canopy with the soil surface between rows completely visible and $5=$ completely closed canopy over the furrow with no soil visible. Porosity is measured at mid pod fill (R5 growth stage, Brick 2005) when canopy closure over the furrow has become well established. Canopy height represents the average distance in $\mathrm{cm}$ from the soil surface to the top of the plant canopy and is synonymous with most plant height measurements. For this study, plant height and canopy height were interchangeable terms. Height was also measured at mid pod fill (R5) before plants lodge. Disease reaction was scored from 1 to 9 based on combined incidence and severity of infection at physiological maturity (R7), where $1=$ no diseased plants; $3=20-30 \%$ diseased plants and/or 5-10\% infected tissue; $5=$ 40-50\% diseased plants and/or 20-30\% infected tissue; $7=60-70 \%$ diseased plants and/or $40-50 \%$ infected tissue; and $9=80-100 \%$ diseased plants and/ or $60-100 \%$ infected tissue. For complete description of the range of scores, refer to Miklas et al. (2001).

For the 2000 and 2001 trials respectively, 110 and 134 dry bean lines and cultivars were tested. A mix of partially resistance and susceptible dry bean lines and cultivars representing many different market classes including black, cranberry, light and dark red kidney, great northern, navy, pink, pinto, and small red beans were included. For the 2000 trial, a plot consisted of four-rows, $3 \mathrm{~m}$ in length, and $0.56 \mathrm{~m}$ row spacing. A few entries with limited seed were planted in single-row plots. The 2001 trial consisted of three-row plots with similar row length and row spacing. Randomized complete-block designs with three replications were used in both years. Market classes were tested in separate experiments. All lines tested across experiments representing the different market classes were combined for subsequent correlation analysis between canopy traits and disease score means.

Snap beans evaluated in white mold disease screening field trials in Corvallis, OR, at the Oregon State University Vegetable Research Farm, from 2002 to 2008, were examined for relationship of lodging and disease severity. A plot consisted of a single row, $5 \mathrm{~m}$ in length, with row spacing of $0.78 \mathrm{~m}$. Lines were replicated four times and arranged in a randomized complete block design. Influence of disease severity on estimated yield was also examined. For the 20022006 trials, disease severity was recorded during seed fill (R5-R6) based on a 1 to 10 score where $1=$ no symptoms and $10=$ all plants in plot were dead; lodging was scored from 1 to 4 (R6), where $1=$ no lodging and 4 = completely lodged; and yield potential (R7) was estimated by 0 to 4 scale, where $0=$ no yield and 4 = high potential yield. Lodging and yield potential in 2007 and 2008 were scored using similar but slightly more compressed, 1 to 3 scales, where $1=$ no lodging or poor yield and $3=$ severe lodging or high yield, respectively. The standard 1 to 9 white mold disease score described above, comprising disease severity and incidence was adopted for the 2007 and 2008 disease ratings. The number of snap bean lines tested ranged from 98 in 2005 to 215 in 2003.

White mold trials conducted at the Montcalm Research Farm, in Entrican, MI, from 2008 to 2011, were examined for association between agronomic traits and white mold disease severity. Each year, the trial consisted of 64 dry bean lines, including the 12 entries from the national Bean White Mold Nursery (BWMN) (McCoy et al. 2012), newer cultivars, advanced breeding lines from the general breeding program, and advanced lines bred for partial resistance to white mold. The lines and cultivars represent a mix of market classes similar to the WA trials. A plot consisted of four rows, $5 \mathrm{~m}$ in length and $0.5 \mathrm{~m}$ spacing between rows. Plots were replicated three times and the experimental design was an $8 \times 8$ square lattice. Yield $\left(\mathrm{kgha}^{-1}\right)$ harvested from the center two rows, seed weight ( $\left(\mathrm{g} 100\right.$ seeds $\left.^{-1}\right)$, canopy height (cm, R6), lodging (1-5), days to flower (DAP, number of days after planting), days to maturity (DAP), desirability (1-7), and the standard white mold disease score (1-9) recorded at physiological maturity (R7) were obtained for each plot. Although, white mold severity was measured as a percentage in 2008 and 2009 trials, the percent severity completely coincided with 
disease score. Lodging was scored at harvest maturity (R8), from 1 for no lodging to $5=$ all plants in the plot completely lodged. Desirability rated at harvest maturity (R8) from 1 to 7 represents an agronomic acceptance index based on visual combination of traits: upright plant habit, resistance to lodging, excellent pod load, favorable high pod placement in the plant canopy, and freedom from disease and is measured at harvest maturity. Values from 1 to 3 would infer that the genotype possesses a major weakness or combination of undesirable traits such as excessive late or early maturity, high disease scores, and a decumbent plant habit; values from 4 to 5 would indicate an overall adapted genotype in terms of maturity, upright architecture with low to moderate disease scores; values from 6 to 7 would indicate a superior genotype in terms of low disease scores, very erect architecture, lodging resistant, excellent pod load and placement. Only those genotypes with values from 5 to 7 would be selected for advance.

Fungicide trials were conducted for 3 years from 2007 to 2009 at the Paterson, WA, research farm to examine the interaction of growth habit and partial physiological resistance on efficacy of fungicide for control of white mold disease. The Type III (decumbent-indeterminate vine growth habit) pinto 'Montrose' (Brick et al. 2001) as a susceptible check, moderately susceptible Type III semi-upright pinto cultivar 'Winchester', and Type II pinto breeding line USPTWM-1 (Miklas et al. 2006) with partial resistance derived from 'Bunsi' navy bean, were included in the 2007 trial. The lines included in the 2008 trial were Type III cultivars 'Quincy' pinto (Hang et al. 2006) and 'Orion' great northern as susceptible checks, upright Type II pinto breeding line PT7-8 with potential disease avoidance, and USPT-WM-1 and 11A-39 (Type II) pintos and 29C-26 (Type III) great northern (Miklas 2007) with partial resistance derived from different sources Bunsi, G122, and NY6020-4, respectively. In 2009, the following lines were included: Quincy and Orion as susceptible checks, upright PT7-8 and 'Matterhorn' great northern (Kelly et al. 1999), and the related pintos USPT-WM-1 and 37-2, and great northern Type II lines 38-4 and 29C-26 with partial physiological resistance.

Although some lines changed from year-to-year, the fungicide treatments remained mostly unchanged. A commercial fungicide Topsin M 70 WP (United Phosphorus Inc., King of Prussia, PA, USA) was used in four spray treatments in 2007: no spray as a control, a single application $\left(1.68 \mathrm{kgha}^{-1}\right)$, split application with two sprays (each spray at $1.68 \mathrm{kgha}^{-1}$ ), and split application with three sprays $\left(1.68 \mathrm{kgha}^{-1}, 1.68 \mathrm{~kg}\right.$ $\mathrm{ha}^{-1}$ and $1.1 \mathrm{kgha}^{-1}$, respectively). For 2008 and 2009 trials, the split application with three sprays was not included as a treatment. The first application was applied at initial flowering (R1) and subsequent applications were applied at 7 to 10 day intervals. The lines by spray treatments were arranged in a randomized complete block design with four replications in 2007 and 2008 and three replications in 2009. Individual plots consisted of four rows as described for the 2000 trial. Canopy porosity (1-5), lodging - using an expanded scale from 1 to 9 , where $1=$ no lodging and 9 = completely lodged, yield $\left(\mathrm{kgha}^{-1}\right)$, and the standard white mold disease score (1-9) described above, were measured all 3 years. Canopy height $(\mathrm{cm})$ was measured in 2007 and days to harvest maturity (DAP) in 2007 and 2009.

For all the field trials (WA, OR, MI), planting density $\left(\sim 230,000\right.$ seeds $\left.\mathrm{ha}^{-1}\right)$, fertilizer and weed control were managed for optimum yields. Frequent applications of water were delivered by overheadsprinklers to provide excess moisture to promote white mold epidemics. Simple phenotypic correlation analyses were conducted with the data obtained for each season and location using the trait means averaged across replications for each line.

\section{Results}

\section{Comparative QTL map}

Six novel QTL for partial resistance to white mold, identified in the straw test by Mkwaila et al. (2011) and Pérez-Vega et al. (2012), were added to the 21 QTL reported by Soule et al. (2011) (Fig. 1). This comprehensive map, now with 27 QTL for partial resistance to white mold, was also populated with 36 QTL conditioning disease avoidance traits. Seventeen of the avoidance trait QTL were obtained from research conducted or reviewed by Soule et al. (2011), 11 were from the two newest white mold QTL studies (Mkwaila et al. 2011; Pérez-Vega et al. 2012), and eight were integrated from studies unrelated to white mold. These 36 QTL coalesced into 18 genomic regions influencing aerial agronomic traits (canopy height, internode length, canopy porosity, and lodging) with possible connection to disease avoidance. 
Thirteen of these regions co-located with 13 of the white mold resistance QTL. Furthermore, 16 additional QTL from unrelated studies were added to the map to examine possible influence of root traits on white mold avoidance in common bean. These 16 QTL coalesced into 10 regions affecting root traits.

The 13 of 27 QTL for white mold resistance associated with QTL for plant architecture and agronomic traits which confer disease avoidance are depicted in Fig. 1. Soule et al. (2011) indicated only three (WM1.1, WM3.1, WM5.3) QTL were associated with disease avoidance traits. WM1.1 ${ }^{\mathrm{AG}, \mathrm{XC}}$ associated with the fin gene for determinacy has a strong influence on growth habit and unsurprisingly is associated with disease avoidance traits such as plant height and canopy porosity (Miklas et al. 2001). QTL controlling root length density and surface area (Cichy et al. 2009) mapped to the same region, indicating possible pleiotropic effect of fin gene on root traits or a linkage between fin and one or more genes controlling root length density and root surface area. The WM3.1 ${ }^{\mathrm{AN}}$ and WM5.3 ${ }^{\mathrm{R} 31}$ QTL detected solely in the field cosegregated with plant height QTL, and WM3.1 correlated with a QTL for canopy porosity as well (Miklas et al. 2007). Park et al. (2001) identified a QTL for plant height near WM5.3 providing additional support that this QTL confers disease avoidance.

Three additional QTL for partial resistance to white mold, WM6.1, WM7.2, and WM8.1, have a straightforward relationship with architectural traits conditioning disease avoidance. For a fourth QTL, WM4.2, the association is less clear. The association with disease avoidance for these four QTL, and the three previously mentioned, is strengthened by co-segregation between disease avoidance traits and resistance to white mold measured within the same mapping population and environment. WM6.1 ${ }^{\mathrm{B} 60, \mathrm{R} 31, \mathrm{XC}}$ expressed in the field and greenhouse straw test was associated with QTL for lodging and plant height within the B60 (Benton/ NY6020-4) mapping population (Miklas et al. 2003). WM6.1 was detected solely in the greenhouse by PérezVega et al. (2012), but the straw test reaction was once again associated with a morphological trait (plant height) measured in the same greenhouse environment and same XC (Xana/C49-242) RIL population. WM7. $2^{\mathrm{BN}, \mathrm{BR}}$, expressed solely in the field, cosegregated with disease avoidance traits in two related populations: lodging, plant height, and branching angle in BN (Bunsi/Newport) RIL population and lodging in
BR (Bunsi/Raven) RIL population. A QTL for root length in DG (Dorado/G18933) RIL population maps near WM7.2. Perhaps the QTL for lodging associated with WM7.2 is influenced by root length. WM8.1 ${ }^{\mathrm{PX}, \mathrm{CG}}$ with greater expression in the greenhouse than field, clearly co-segregated with QTL for canopy porosity and plant height detected in the same PX (PC-50/ XAN-159) RIL population. WM8.1 was originally detected in the GC (G122/CO72548) RIL population, but only in the field, suggesting influence by a disease avoidance trait was plausible.

Although measured in the same TL (Tacana/landrace) RIL population, the association of WM4. $2^{\mathrm{R} 31, \mathrm{TL}}$ with avoidance is slightly less convincing, because partial resistance and avoidance traits (lodging, plant height) were measured in different environments, the greenhouse and field, respectively (Mkwaila et al. 2011). Perhaps plant height and lodging traits expressed in the field contributed to a morphological effect in the

Fig. 1 Linkage groups ( chromosomes) 1 through 11 of common bean, showing previously identified QTL for resistance to white mold with WM prefixes [note white mold resistance QTL descriptions follow new QTL nomenclature guidelines (Miklas and Porch 2010), whereas names for the QTL for agronomic and avoidance traits mentioned herein are not standardized. A brief explanation of nomenclature follows using WM1.1 $1^{\mathrm{AG}, \mathrm{XC}}$ as an example; the trait abbreviation 'WM' is followed by the chromosome (1) and order of discovery (1st) for QTL on the same chromosome, with the mapping population designations as superscripts, ordered by original discovery population AG (A55/G122) and subsequent validating population(s) XC (Xana/C49-242). The mapping population superscripts are usually only included within the text at first mention.] (black bars indicate QTL detection in the field, light gray bars detection in the greenhouse straw test, and hatched bars detection in both field and greenhouse), disease avoidance traits in green boxes ( $L D G$ lodging, $H T$ canopy or plant height, $I L$ internode length, $C P$ canopy porosity, $A G$ branch angle, $I W$ internode width), and root traits in red boxes (Rlf root length field, $S r l$ specific root length; Trd tap root dry weight, $R L D$ root length density, $R S A$ root surface area) originally mapped in recombinant inbred line (RIL) populations Bunsi/Raven (BR; Ender and Kelly 2005), Bunsi/Newport and Huron/Newport (BN and HN; Kolkman and Kelly 2003), G122/CO72548 (GC; Maxwell et al. 2007), A55/ G122 (AG; Miklas et al. 2001), Benton/NY6020-4 (B60; Miklas et al. 2003), Aztec/ND88-106-04 (AN; Miklas et al. 2007), PC-50/ XAN-159 (PX; Park et al. 2001), Xana/C49-242 (XC; Pérez-Vega et al. 2012), Tacana/PI 318695 and Tacana/PI 313850 (TW and TL; Mkwaila et al. 2011), DOR 364/G19833 (DG; Beebe et al. 2006), OAC Seaforth/OAC 95-4 (S95; Tar'an et al. 2002); G2333/ G19839 (GG; Checa and Blair 2008); and G19833/AND 696 (GA; Cichy et al. 2009). The linkage groups are composed of markers detailed by the BAT 93/Jalo EEP558 (BJ; Freyre et al. 1998) and DG (Blair et al. 2003) core maps and comparative map for white mold resistance QTL from Soule et al. (2011) 

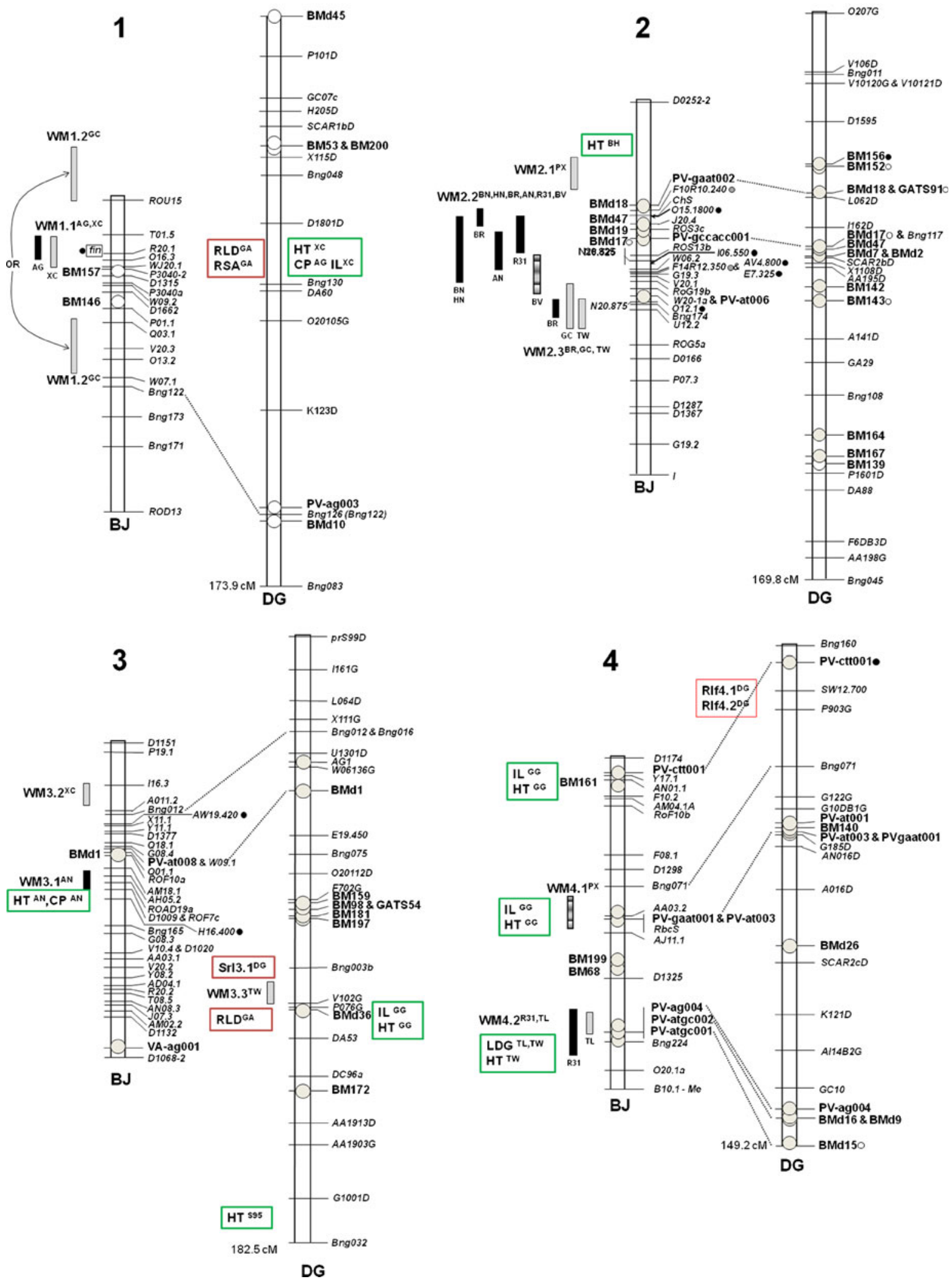

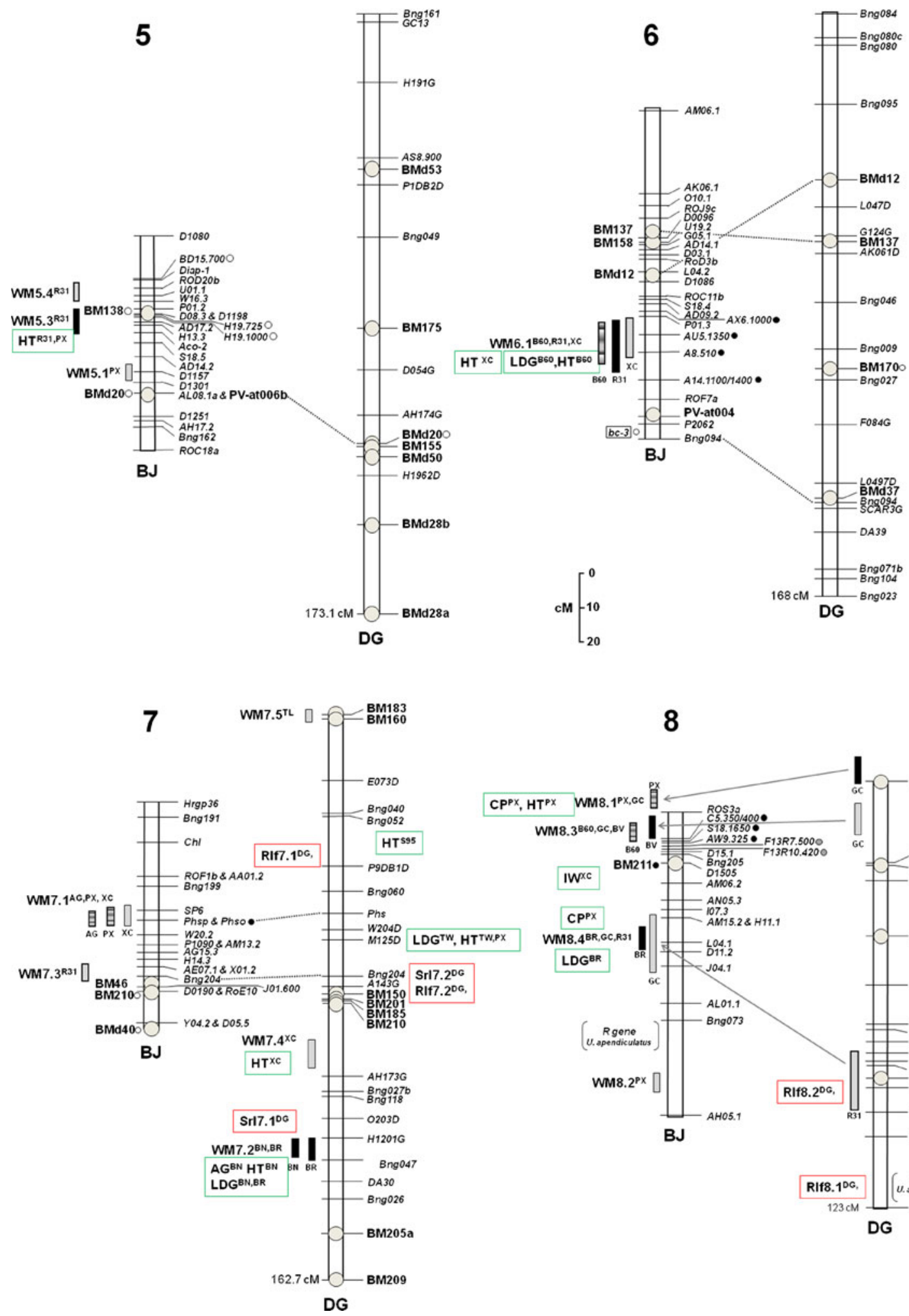

8

Fig. 1 continued. 

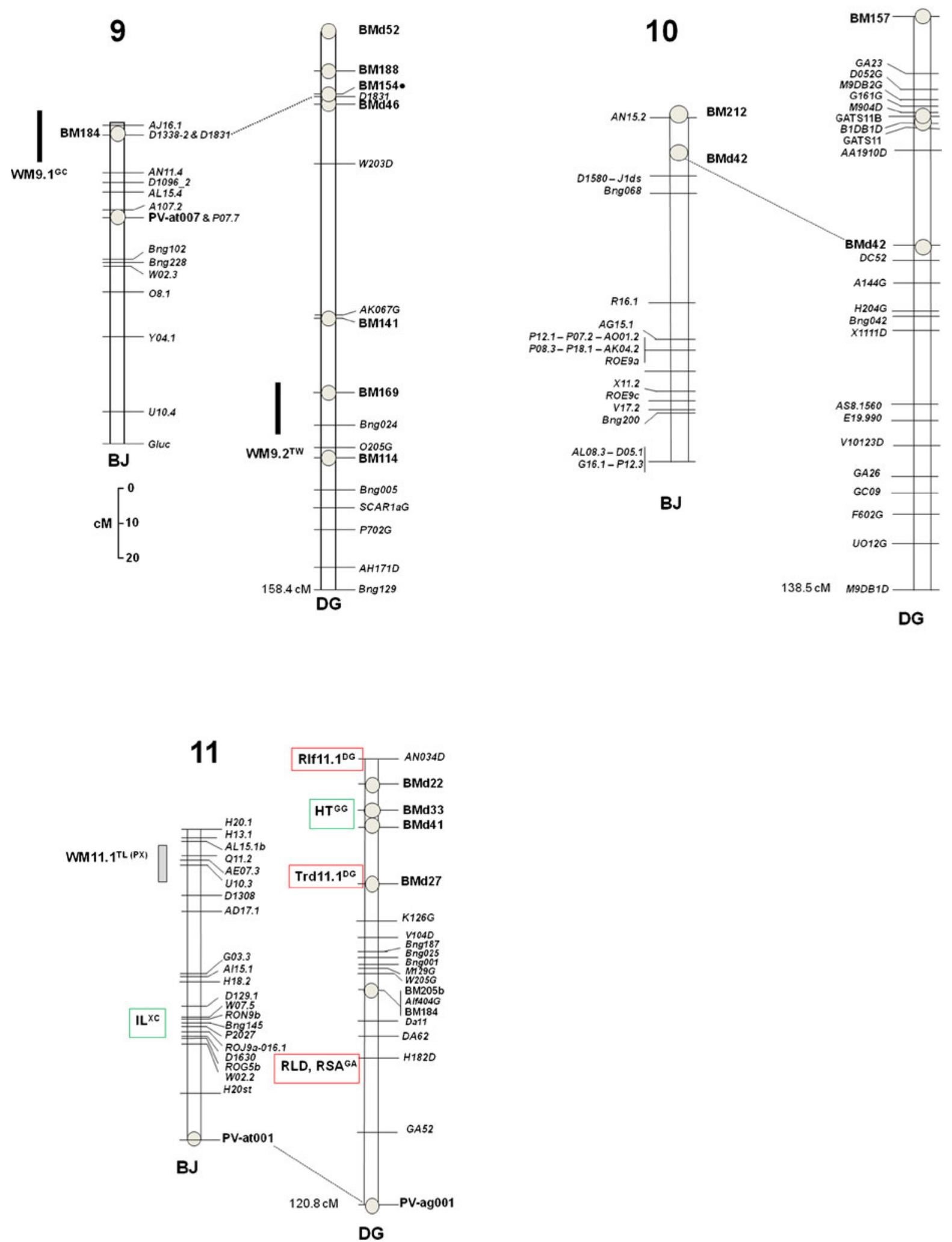

Fig. 1 continued. 
greenhouse straw test reaction leading to detection of WM4.2. A QTL for lodging detected in the TW (Tacana/wild) RIL population maps to the same region. Expression of WM4.2 solely in the field in a different R31 (Raven/I9365-31) RIL population (Soule et al. 2011) supports evidence that the QTL could be influenced by a disease avoidance trait. Lodging was not measured in the R31 population.

The co-localizations of WM2.1, WM3.3, WM4.1, WM7.1, WM7.4, and WM8.4, with QTL conditioning disease avoidance traits are speculative, primarily because the QTL were mapped in different populations with few common markers, and for other reasons detailed below (Fig. 1). WM2.1 ${ }^{\mathrm{PX}}$ detected in the straw test in a population derived from a cross between two Andean lines occurs in the vicinity of a QTL for plant height measured in a navy bean population. WM3.3 $3^{\mathrm{TW}}$ identified by the straw test, is loosely associated with QTL from other populations for root length (Beebe et al. 2006) and density (Cichy et al. 2009), and internode length and plant height (Checa and Blair 2008). WM4.1 ${ }^{\mathrm{PX}}$ expressed in the field and greenhouse was associated with QTL for internode length and height detected in a different GG (G2333/G19839) RIL population (Checa and Blair 2008). WM7.1 ${ }^{\mathrm{AG}, \mathrm{PX}, \mathrm{XC}}$ is located in the midst of avoidance and root traits measured in other populations, but none map to the specific location of the white mold resistance QTL at the Phaseolin seed protein $(P h s)$ locus. WM7.4 ${ }^{\mathrm{XC}}$ was detected solely in the straw test and co-segregates with a QTL for plant height measured in the greenhouse in the same $\mathrm{XC}$ population. WM8.4 ${ }^{\mathrm{BR}, \mathrm{CG}, \mathrm{R} 31}$ was detected by greenhouse methods in two separate populations (Maxwell et al. 2007; Soule et al. 2011); and in the field for a third population. It had a minor effect in all three cases, but WM8.4 detected in the field in BR population (Ender and Kelly 2005) was associated with a minor QTL for lodging in the same population. A QTL for root length identified in a different population (Beebe et al. 2006) mapped to the same region as WM8.4, and similar to the observation made for WM7.2, which suggests a relationship between root length and lodging. A QTL for canopy porosity in PX population is located in the same WM8.4 region.

Other than a few putative co-localizations of root trait QTL with WM1.1, WM3.3, WM7.2, and WM8.4, QTL primarily associated with disease avoidance, the root trait QTL mapped independent of the other 23 WM QTL. The putative co-localization of root length with lodging for WM7.1, WM7.2 and WM8.4, suggests a possible role of root traits in supporting upright plants and resistance to lodging for avoiding white mold disease. Analysis of root traits, lodging, and reaction to white mold within the same population tested across multiple trials is needed to validate these putative associations.

White mold screening field trials

Disease avoidance traits, canopy porosity and canopy height, were significantly correlated with disease severity in both Washington field trials (Table 1). For each trial, a more open or taller canopy was correlated with less white mold. The correlations were weaker in 2001 compared to 2000. Greater disease pressure in 2001, as indicated by higher mean disease score, 7.3, compared to 5.5 in 2000, for 39 lines common to both trials, may have partly overcome the effectiveness of

pools, tested in white mold screening trials conducted in Paterson, WA, in 2000 and 2001
Table 1 Simple correlation coefficients $(r)$ between canopy trait and disease score means for dry bean breeding lines and cultivars, representing many different market classes and gene

\begin{tabular}{lcccccc}
\hline & Year & $\begin{array}{l}\text { Lines } \\
\text { No. }\end{array}$ & $\begin{array}{l}\text { Mean disease score } \\
1 \text { to } 9\end{array}$ & $\begin{array}{l}\text { Canopy porosity (1 to 5) } \\
r\end{array}$ & Canopy height (cm) $^{\mathrm{b}}$ \\
\hline Disease score (1 to 9) all genotypes & 2000 & 110 & 5.3 & $0.82^{* *}$ & $-0.62^{* *}$ \\
& 2001 & 134 & 6.8 & $0.36^{* *}$ & $-0.33^{* *}$ \\
Disease score (1 to 9) common genotypes & 2000 & 39 & 5.5 & $0.78^{* *}$ & $-0.60^{* *}$ \\
& 2001 & 39 & 7.3 & $-0.39 *$ \\
\hline
\end{tabular}

\footnotetext{
${ }^{\text {a }}$ Disease score, $1=$ no symptoms and $9=$ completely diseased

${ }^{\mathrm{b}}$ Canopy porosity, $1=$ completely open and $5=$ completely closed

$*$,** significant correlations at the $<0.05$ and $<0.01$ level of probability, respectively
} 
disease avoidance traits conferred by open and tall plant canopies. Supporting evidence for this is the higher disease scores exhibited (6.7 and 6.8) by upright lines with narrow plant profiles, such as 'Claret' (Hosfield and Hang 2005) and MSU-396 breeding line in 2001, than observed in 2000 under lower disease pressure, 2.0 and 2.8 , respectfully.

For the snap bean trials in Oregon, there was a significant correlation between disease score and lodging in each trial, and the association was moderately high averaging $63 \%$ across trials (Table 2). Disease severity was negatively correlated with yield in 5 of 7 years. The yield reduction from increased disease severity was greatest in 2004 and weakest in 2008, the trials with highest and lowest disease pressure, respectively. Although the snap beans tested had determinate Type I bush growth habits, they differed for upright plant architecture and corresponding ability to be resistant or susceptible to lodging. One might expect increased lodging to result from plants with high yield potential falling over from the greater pod (weight) load. But, the opposite was observed, increased lodging was associated with lower yield $\left(r=-0.34^{* *}\right)$ in snap bean across 7 years. The negative correlation likely results from lodged plants suffering yield loss from the greater disease pressure.

The white mold screening field trials conducted in Michigan showed that resistance to lodging was an extremely important white mold avoidance trait in dry bean (Table 3). Resistance to lodging was consistently correlated $(57 \%)$ with reduced disease in all 3 years. Desirability score and maturity were correlated with disease score in three of the 4 years. Desirability score itself was highly and consistently correlated with high yield potential $46 \%$, resistance to lodging $50 \%$, and increased plant height $63 \%$ in all four trials (data not shown). Thus, the desirability score reflects an index of the aforementioned traits representing an ideal dry bean ideotype with the added benefit of greater white mold avoidance. Interestingly, canopy height, an important disease avoidance trait and component of desirability score was negatively correlated with disease score but significantly only in the 2011 trial. The 2010 trial had much higher disease pressure, and was the only trial to show a significant negative correlation between yield and disease score. Avoidance traits are less effective and yield more vulnerable under heavier white mold pressure.

\section{Fungicide efficacy}

In general, fungicide applications to manage white mold reduced disease severity and increased yield each year (Figs. 2 and 3). There was a significant line by treatment interaction for disease severity score each year (2008-2009) and for yield in 2007 (Table 4). For 2007, fungicide application revealed a greater magnitude of effect in managing white mold on the

Table 2 Simple correlation coefficients $(r)$ among disease score and yield and lodging means for snap bean breeding lines and cultivars, tested in white mold screening trials conducted in Corvallis, OR, from 2002 to 2008

\begin{tabular}{|c|c|c|c|c|c|}
\hline & Year & $\begin{array}{l}\text { Lines } \\
\text { No. }\end{array}$ & $\begin{array}{l}\text { Mean disease score } \\
\text { (1 to } 10)\end{array}$ & $\begin{array}{l}\text { Yield estimate }(0 \text { to } 4)^{\mathrm{b}} \\
\mathrm{r}\end{array}$ & Lodging $(1 \text { to } 4)^{\mathrm{c}}$ \\
\hline \multirow[t]{6}{*}{ Disease score (1 to 10$)$} & 2002 & 105 & 5.8 & $-0.30 * *$ & $0.71 * *$ \\
\hline & 2003 & 215 & 5.6 & $-0.25 * *$ & $0.79 * *$ \\
\hline & 2004 & 151 & 8.0 & $-0.67 * *$ & $0.75 * *$ \\
\hline & 2005 & 98 & 4.7 & 0.08 & $0.65 * *$ \\
\hline & 2006 & 125 & 5.4 & $-0.64 * *$ & $0.38 * *$ \\
\hline & & & (1 to 9$)$ & (1 to 3 ) & (1 to 3 ) \\
\hline \multirow[t]{2}{*}{ Disease score (1 to 9 ) } & 2007 & 142 & 4.1 & $-0.26^{* *}$ & $0.77 * *$ \\
\hline & 2008 & 101 & 3.0 & 0.18 & $0.35 * *$ \\
\hline
\end{tabular}

\footnotetext{
${ }^{\text {a }}$ White mold scores: $1-10,1=$ no symptoms observed, $10=$ all plants in plot infected; $1-9$ infected, and standard $1-9$ scale, where $1=$ no disease and $9=$ completely diseased

${ }^{\mathrm{b}}$ Yield estimated with $0-4$ scale with $0=$ poor yield and $4=$ high yield potential; $1-3$ scale with $1=$ poor yield and $3=$ good yield potential

${ }^{\mathrm{c}}$ Lodging based on $1-4$ scale with $1=$ upright and $4=$ prostrate; $1-3$ scale with $1=$ upright and $3=$ prostrate
} 
Table 3 Simple correlation coefficients $(r)$ between disease severity and agronomic trait means for dry bean lines and cultivars, representing many different market classes and gene pools, tested in white mold screening trials conducted in Entrican, MI, from 2008 to 2011

\begin{tabular}{lccccccccc}
\hline & Year & $\begin{array}{l}\text { Mean } \\
\text { disease } \\
\text { score } \\
1 \text { to } 9\end{array}$ & $\begin{array}{l}\text { Yield } \\
\left(\mathrm{kgha}^{-1}\right)\end{array}$ & $\begin{array}{l}\text { Seed weight } \\
\left(\mathrm{g} 100 \mathrm{seeds}^{-1}\right)\end{array}$ & $\begin{array}{l}\text { Days to } \\
\text { flower (d) }\end{array}$ & $\begin{array}{l}\text { Days to } \\
\text { maturity (d) }\end{array}$ & $\begin{array}{l}\text { Lodging } \\
(1 \text { to 5) }\end{array}$ & $\begin{array}{l}\text { Canopy } \\
\text { height }(\mathrm{cm})\end{array}$ & $\begin{array}{l}\text { Desirability } \\
(1 \text { to } 7)^{\mathrm{c}}\end{array}$ \\
\hline Disease score (1 to 9) & 2008 & 3.3 & 0.09 & -0.24 & $0.30^{*}$ & $-0.31^{*}$ & $0.70^{* *}$ & -0.03 & $-0.49^{* *}$ \\
& 2009 & 3.5 & -0.23 & -0.10 & 0.08 & -0.22 & $0.56^{* *}$ & -0.20 & $-0.52^{* *}$ \\
& 2010 & 5.7 & $-0.34^{* *}$ & 0.06 & $-0.27^{*}$ & $-0.47^{* *}$ & $0.48^{* *}$ & -0.19 & $-0.44^{* *}$ \\
& 2011 & 3.6 & 0.03 & 0.06 & -0.07 & $-0.51^{* *}$ & $0.53^{* *}$ & $-0.50^{* *}$ & -0.20 \\
\hline
\end{tabular}

${ }^{\text {a }}$ Disease score, $1=$ no symptoms and $9=$ completely diseased

${ }^{\mathrm{b}}$ Lodging, $1=$ no lodging and $5=$ completely lodged

${ }^{\mathrm{c}}$ Desirability index, $1=$ worst and $7=$ best

*,** significant correlations at the $<0.05$ and $<0.01$ level of probability, respectively

susceptible check Montrose, lesser effect on the upright susceptible line Winchester, and least effect in the partially resistance line USPT-WM-1 (Fig. 2). The percent reduction in disease score with a single fungicide application was 81,65 , and $50 \%$ for Montrose, Winchester, and USPT-WM-1, respectively. One or more fungicide applications had the greatest impact on yield in Montrose and no significant effect on yield in USPTWM-1 (Fig. 3). Similar lack of a yield benefit from fungicide application for USPT-WM-1 was observed in 2008 and 2009. The yield for pinto 37-2 (released as USPT-WM-12) which derives resistance, in part, from USPT-WM-1, likewise did not respond to fungicide application in the 2009 trial. For the non-treated control treatments, it is noteworthy, that yield for USPTWM-1 matched or exceeded yield of the susceptible checks all three years, with the possible exception of Orion. Although, Orion may have yielded slightly more, the seed weight (data not shown) was $9 \%$ less in the non-spray treatment compared to the dual application of fungicides which indicates seed quality suffered without fungicide protection. Seed weight for USPT-WM-1, was unaffected by spray treatment.

It is evident that susceptible lines benefit the most from fungicides to control white mold. Little benefit was observed in 2007 with two fungicide applications except for the susceptible check Montrose where disease severity was reduced with a second application from a score of 2.9 to 1.6 (Fig. 2). There was also an effect from a third fungicide application on yield for susceptible cultivars Montrose and Winchester in 2007, but split applications with three sprays are not a common practice among dry bean growers (Fig. 3). Similarly in 2008, except for the very susceptible Orion, dual applications did not significantly improve the control of disease severity above the effect of a single application. In general, no yield benefit from a second fungicide application in 2008 was observed, with 11A-39 pinto being the one exception. There was higher disease pressure in the 2009 trial, so this trial showed a benefit from dual applications as five of eight lines exhibited a significant reduction in disease severity score. Moreover, the dual applications significantly increased yield for Matterhorn by $24 \%$ more than the single application. This result underscores why growers in white mold prone production regions prefer two separate fungicide applications for control of white mold.

The susceptible checks with more upright architecture, Winchester in 2007, PT7-8 in 2008, and PT7-8 and Matterhorn in 2009, had more porous canopies and resistance to lodging than the susceptible checks (Table 5). The upright (Type II) susceptible checks had lower disease severity than the decumbent (Type III) susceptible checks, with no spray or a single fungicide application, in 2007 and 2008, but not in 2009 (Fig. 2). The checks with upright architecture likely exhibited partial avoidance of white mold in the years with moderate disease pressure but avoidance was not effective under the heavier disease pressure that occurred in 2009. The upright checks, under heavy pressure in 2009, responded well to the fungicide applications, with lower disease severity and increased yield. The yield response for the upright checks in 2007 and 2008 to fungicide applications was minimal compared to the susceptible 
Fig. 2 Dry bean line $x$ spray treatment interaction on the effect of fungicide applications ( 0 - no spray, 1 $=$ single application, 2 = dual applications 7 to 10 days apart, and 3 - split applications 7-10 days apart), on disease severity (1 to 9 score where $1=$ no disease and $9=$ completely diseased) in trials conducted in Paterson, WA, 2007 to 2009; S, US, and PR, represent susceptible, upright susceptible and partially resistant dry bean lines, respectively; bars represent LSD 0.05 mean separation test for the genotype $\mathrm{x}$ treatment interaction; overlapping bars indicate lack of significant difference
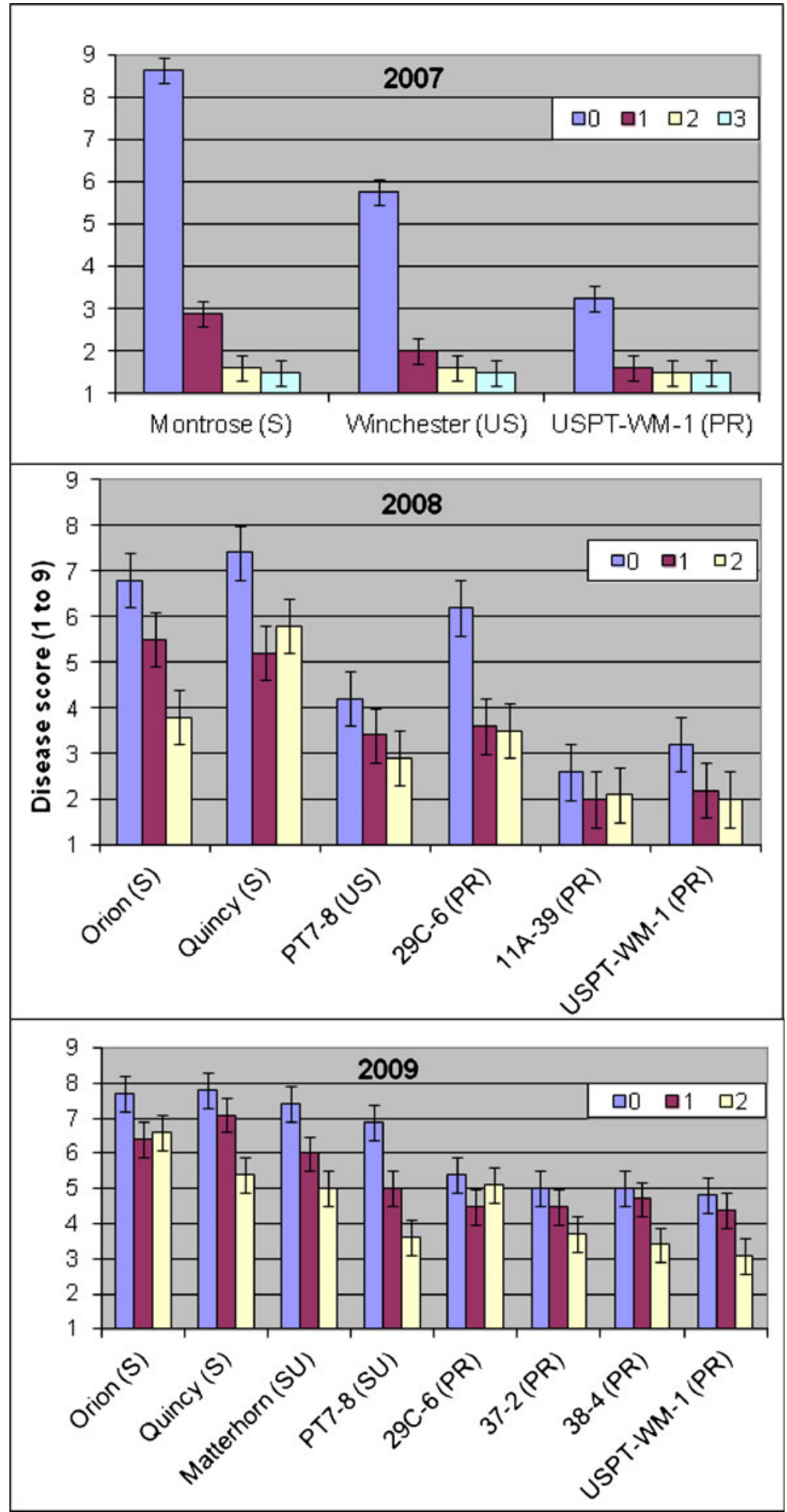

checks, providing additional support that disease avoidance is more effective in combating moderate disease pressure (Fig. 3). USPT-WM-1 possesses physiological resistance in combination with disease avoidance due to upright architecture which is the reason it performed so well without fungicide protection. 
Fig. 3 Dry bean line $x$ spray treatment interaction on effect of fungicide applications $(0-$ no spray, $1=$ single application, $2=$ dual applications 7 to 10 days apart, and 3 - split applications 7-10 days apart), on grain yield in trials conducted in Paterson, WA, 2007 to 2009; S, US, and PR, represent susceptible, upright susceptible and partially resistant dry bean lines, respectively; bars represent LSD 0.05 mean separation test for the genotype $\mathrm{x}$ treatment interaction; overlapping bars indicate lack of significant difference
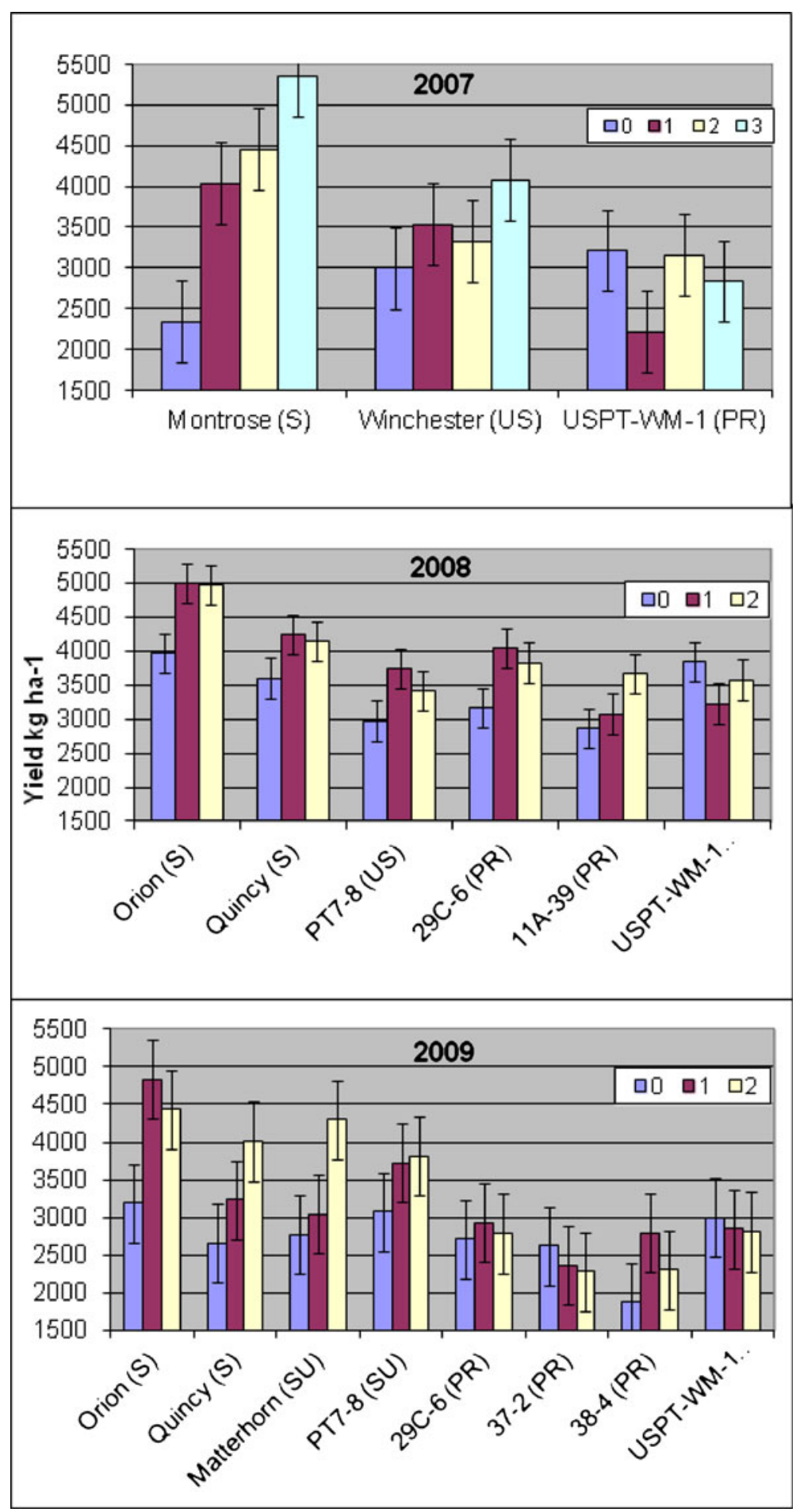

\section{Discussion}

The identification of numerous QTL, widely distributed across the genome, attest to the genetic complexity of white mold resistance in common bean. Breeders and geneticists have struggled to identify major QTL for marker-assisted breeding (MAS) applications, and to separate the effects of the QTL on disease reaction. 
Table 4 Analysis of variance results for disease score and yield to examine effect of dry bean line on fungicide efficacy in white mold trials conducted in Paterson, WA, 2007-2009

\begin{tabular}{|c|c|c|c|c|c|}
\hline \multirow[t]{2}{*}{ Source } & \multirow[t]{2}{*}{ df } & \multicolumn{2}{|c|}{ Disease score $(1-9)^{\mathrm{a}}$} & \multicolumn{2}{|c|}{ Yield $\left(\mathrm{kgha}^{-1}\right)$} \\
\hline & & MS & $\mathrm{F}$ value & MS & $\mathrm{F}$ value \\
\hline \multicolumn{6}{|l|}{2007} \\
\hline Rep & 3 & 0.57 & NS & 2483891 & $4.8^{* *}$ \\
\hline Trt & 3 & 52.10 & $256.11 * *$ & 2759216 & $5.3 * *$ \\
\hline Line & 2 & 11.44 & $56.22 * *$ & 4507176 & $8.8^{* *}$ \\
\hline Line*Trt & 6 & 6.39 & $31.40 * *$ & 1853560 & $3.6^{* *}$ \\
\hline Error & 33 & 0.20 & & 511490 & \\
\hline \multicolumn{6}{|l|}{2008} \\
\hline Rep & 3 & 1.52 & NS & 191203 & NS \\
\hline Trt & 2 & 14.38 & $21.76^{* *}$ & 1129315 & $6.7^{* *}$ \\
\hline Line & 5 & 25.73 & $38.94 * *$ & 2383231 & $14.1 * *$ \\
\hline Line*Trt & 10 & 1.33 & $2.01 *$ & 194949 & NS \\
\hline Error & 44 & 0.66 & & 169163 & \\
\hline \multicolumn{6}{|l|}{2009} \\
\hline Rep & 2 & 1.72 & $4.15^{*}$ & 946986 & NS \\
\hline Trt & 2 & 14.61 & $35.31 * *$ & 1173280 & NS \\
\hline Line & 7 & 9.88 & $23.89 * *$ & 2302910 & $5.05 * *$ \\
\hline Line*Trt & 14 & 0.96 & $2.32 *$ & 396742 & NS \\
\hline Error & $45(25)^{\mathrm{b}}$ & 0.41 & & 456323 & \\
\hline
\end{tabular}

${ }^{a}$ Disease score, $1=$ no disease and $9=$ completely diseased

${ }^{\mathrm{b}}$ There were fewer degrees of freedom for yield in 2009 because some plots were not harvested

*,** significant at the $<0.05$ and $<0.01$ level of probability, respectively

The updated comparative map helps to discern QTL function and to select candidate QTL for MAS. The map showed that nearly half of the 27 QTL for white mold resistance, detected to-date, have a possible association with QTL for white mold disease avoidance, either through pleiotropic or linkage effects. The previous relationships of six QTL (WM1.1, WM3.1, WM5.3, WM6.1, WM7.2, WM8.1) with disease avoidance traits were strengthened, while seven others (WM2.1, WM3.3, WM4.1, WM4.2, WM7.1, WM7.4, WM8.4) are presented for future validation.

It was previously accepted that QTL for resistance to white mold identified by the greenhouse straw test, or both field and greenhouse tests, were likely conferred by physiological resistance mechanisms (eg. WM2.2, WM7.1, WM8.3), and those QTL expressed solely in the field by disease avoidance traits (eg. WM3.1, WM5.3, WM7.2). The former QTL represent ideal candidates for MAS to improve physiological resistance because they lack association with disease avoidance traits. For this reason, and validated major effect in multiple populations, WM7.1 and WM8.3 of Andean origin were chosen, and used successfully for markerassisted transfer of physiological resistance (Miklas 2007) into Middle American dry bean market classes. Nonetheless, acceptable agronomic types with moderate to high yield potential have yet to be recovered from lines with physiological resistance derived from these MAS efforts, as observed in the poor yield performance of advanced lines 11-39A pinto with WM7.1 and 29C-6 great northern with WM8.3 in the fungicide efficacy trials. Additional marker-assisted backcrossing of these two QTL into pinto and great northern dry bean is ongoing in an attempt to overcome the apparent negative linkage drag effect on yield and agronomic adaptation.

The linkage drag problem raises another concern for many of the 13 QTL associated with disease avoidance, as to how their breeding value may be affected by derivation from wide crosses: Middle American $\mathrm{x}$ Andean, dry bean $\mathrm{x}$ snap bean, and cultivated $\mathrm{x}$ landrace 
Table 5 Summary of disease avoidance traits for dry bean lines averaged across fungicide spray treatments conducted from 2007 to 2009

\begin{tabular}{|c|c|c|c|c|c|c|}
\hline Line & Disease reaction & $\begin{array}{l}\text { Growth habit } \\
\text { Type }\end{array}$ & $\begin{array}{l}\text { Canopy porosity } \\
1 \text { to } 5\end{array}$ & $\begin{array}{l}\text { Lodging }^{\mathrm{c}} \\
1 \text { to } 9\end{array}$ & $\begin{array}{l}\text { Harvest maturity } \\
\text { d }\end{array}$ & $\begin{array}{l}\text { Canopy height } \\
\mathrm{cm}\end{array}$ \\
\hline \multicolumn{7}{|l|}{2007} \\
\hline Montrose & Susceptible & III & 4.1 & 7.9 & 102 & 26.2 \\
\hline Winchester & Upright susceptible & III & 2.9 & 5.8 & 98 & 32.8 \\
\hline USPT-WM1 & Partially resistant & II & 2.9 & 3.6 & 112 & 40.6 \\
\hline LSD 0.05 & & & 0.4 & 0.6 & 1.7 & 0.8 \\
\hline \multicolumn{7}{|l|}{2008} \\
\hline Orion & Susceptible & III & 4.3 & 8.2 & & \\
\hline Quincy & Susceptible & III & 2.7 & 7.2 & & \\
\hline PT7-8 & Upright susceptible & II & 2.2 & 3.9 & & \\
\hline PS02-029C-6 & Partially resistant & III & 3.6 & 6.7 & & \\
\hline PS02-011A-39 & Partially resistant & II & 1.3 & 2.7 & & \\
\hline USPT-WM-1 & Partially resistant & II & 2.5 & 4.2 & & \\
\hline LSD 0.05 & & & 0.4 & 0.7 & & \\
\hline \multicolumn{7}{|l|}{2009} \\
\hline Orion & Susceptible & III & 3.9 & 7.9 & 105 & \\
\hline Quincy & Susceptible & III & 4.0 & 8.0 & 105 & \\
\hline Matterhorn & Upright susceptible & II & 3.7 & 6.7 & 107 & \\
\hline PT7-8 & Upright susceptible & II & 3.0 & 4.6 & 109 & \\
\hline PS02-029C-6 & Partially resistant & II & 3.7 & 6.3 & 114 & \\
\hline PS02-037-2 & Partially resistant & II & 4.9 & 7.8 & 115 & \\
\hline PS02-038-4 & Partially resistant & II & 4.8 & 7.3 & 115 & \\
\hline USPT-WM-1 & Partially resistant & II & 4.5 & 7.6 & 116 & \\
\hline LSD 0.05 & & & 0.5 & 0.6 & 2.1 & \\
\hline
\end{tabular}

${ }^{\text {a }}$ Growth habit: Type III = prostrate indeterminate vine, Type II = upright short indeterminate vine

${ }^{\mathrm{b}}$ Canopy porosity $1=$ completely open and $5=$ completely closed

${ }^{\mathrm{c}}$ Lodging, $1=$ no lodging and $9=$ completely lodged

or wild. It is well known that non-adapted plant types abound in populations derived from such wide crosses. Thus, QTL for white mold resistance identified in populations from wide crosses may represent associations with undesirable avoidance traits, such as long spindly internodes or short plants, with low yield potential. For instance, determinant bush growth habit segregating in the AG population (Middle American x Andean) was associated with smaller plants with low yield potential which contributed to disease avoidance and detection of WM1.1 at the fin locus. Snap bean with unconventional bush growth habits exhibiting taller plants with longer internodes and lower yield potential has been associated with WM6.1 (Miklas et al. 2003). Furthermore, those QTL detected by the straw test but confounded by plant morphology (e.g. WM1.1, WM3.3, WM6.1, WM7.4) trace to un-adapted germplasm generated by wide crosses; thus, may be undesirable for use in improving either physiological resistance or disease avoidance.

The transfer of QTL using narrower crosses within gene pools (e.g. WM2.2, WM3.1, WM7.2) has met with better success, but it has been accomplished by traditional breeding. USPT-WM-1 pinto with resistance derived from a navy bean is a product of hybridization between lines within the Middle American gene pool. The recent releases, USPT-WM-12 (Miklas et al. 2012) and 'Eldorado' pinto (Kelly et al. 2012), combine yield potential with high levels of resistance to white mold conferred by physiological mechanisms and disease avoidance characteristics. These new releases derive from narrow crosses conducted between USPT-WM-1 and great northern and 
pinto bean breeding lines, respectively, with upright architecture and moderate to high yield potential, but susceptibility to white mold.

New RIL mapping populations (USPT-WM-1 $\mathrm{x}$ susceptible upright pintos) appear to have detected an effect for WM2.2 and WM3.1 in the straw test (Mkwaila and Kelly 2012). WM2.2 from the Bunsi source, and WM3.1, were previously only detected by field reaction to white mold. WM3.1 was associated with the stay-green stem trait which may influence both physiological resistance and avoidance mechanisms contributed by open and upright canopies (Fig. 2), in addition to later maturity (Miklas et al. 2006). WM2.2 was detected by the straw test in a snap bean x kidney bean population (Soule et al. 2011). Although, the new releases USPT-WM-12 and Eldorado possess more resistance to white mold in the straw test than USPT-WM-1 (Kelly et al. 2012; McCoy et al. 2012; Miklas et al. 2012), they were selected for resistance solely in field trials.

Given the complexity of white mold reaction and confounding effect of avoidance traits and physiological resistance mechanisms in both field and greenhouse environments, genotypic selection based on QTL assays specifically to improve disease avoidance traits is unlikely until the relative effect of QTL conditioning white mold avoidance traits can be validated in commercially adapted and high yielding genetic backgrounds. Instead, breeders should focus on selecting for resistance to white mold in the field to improve disease avoidance. The multi-location field nurseries spanning 12 years provide unequivocal evidence for the importance of disease avoidance for combating white mold disease. Clearly, dry and snap bean lines with upright architecture, tall plants with narrow profiles, porous canopies, and resistance to lodging have much greater capacity to avoid white mold disease. With the prominence of upright Type II dry bean and Type I snap bean cultivars, resistance to lodging could be the single most important avoidance trait for reducing disease severity. Lodged dry and snap beans create denser and more compact canopies which result in cooler and more humid microclimates favourable to the pathogen. In addition, plant organs in contact with the ground are vulnerable to mycelia infections emanating from colonized senescent blossoms and leaf litter on the soil surface.

Developing resistant lines with mid-season maturity has been a struggle for breeders, as most lines with partial resistance to white mold are later maturing. The association of later maturity with less disease in the Michigan trials may result from a combination of factors. But the negative correlation is most likely due to inclusion of advanced lines that are late because they possess the stay-green stem trait which contributes to physiological resistance. USPT-WM-1 and Eldorado pinto genotypes fit this profile, and both have been used to develop many of the advanced pinto bean lines in various stages of testing for resistance to white mold.

It is encouraging that high enough levels of resistance to white mold have been developed in dry bean (USPT-WM-1 and derived lines) to protect yield potential and seed quality in the absence of fungicide application. The challenge for breeders will be to decrease maturity and increase overall yield potential of dry bean lines with partial physiological resistance to white mold to match the earlier maturity and yield potential exhibited by susceptible lines when protected by a fungicide or when grown in absence of white mold disease. The new pinto bean releases USPTWM-12 and Eldorado, reinforce the importance of field selection for white mold resistance under disease pressure to incorporate physiological resistance in combination with disease avoidance and high yield potential. Advanced yield trials in non-disease nurseries should also be employed to select for higher yield potential and enhanced disease avoidance among white mold resistant bean breeding lines and cultivars.

Acknowledgments The authors would like to thank the National Sclerotinia Initiative for funding part of this research (http://www.ars.usda.gov/Research/docs.htm?docid=20317), and appreciate technical support from Jennifer Trapp, and the many field technicians and graduate students who managed the field trials and collected data.

\section{References}

Allen, D. J. (1983). The pathology of tropical food legumes: disease resistance in crop improvement. Chichester: Wiley.

Ando, K., Grumet, R., Terpstra, K., \& Kelly, J. D. (2007). Manipulation of plant architecture to enhance crop disease control. CAB Reviews: Perspectives in Agriculture, Veterinary Science, Nutrition, and Natural Resources, 2 (026), 1-8.

Beebe, S. E., Rojas-Pierce, M., Yan, X. L., Blair, M. W., Pedraza, F., Muñoz, F., et al. (2006). Quantitative trait loci for root architecture traits correlated with phosphorus acquisition in common bean. Crop Science, 46, 413-423. 
Blad, B. L., Steadman, J. R., \& Weiss, A. (1978). Canopy structure and irrigation influence white mold disease of dry edible beans. Phytopathology, 68, 1431-1437.

Blair, M. W., Pedraza, F., Buendia, H. F., Gaitán-Solís, E., Beebe, S. E., Gepts, P., et al. (2003). Development of a genome-wide anchored microsatellite map for common bean (Phaseolus vulgaris L.). Theoretical and Applied Genetics, 107, 1362-1374.

Boland, G. J., \& Hall, R. (1994). Index of plant hosts of Sclerotinia sclerotiorum. Canadian Journal of Plant Pathology, 16, 93-108.

Brick, M. A. (2005). The bean plant. In H. F. Schwartz, J. R. Steadman, R. Hall, \& R. L. Forster (Eds.), Compendium of bean diseases (2nd ed., pp. 1-5). St. Paul, MN: APS Press.

Brick, M. A., Schwartz, H. F., Ogg, J. B., Johnson, J. J., \& Judson, F. (2001). Registration of 'Montrose' Pinto bean. Crop Science, 41, 260-260.

Checa, O. E., \& Blair, M. W. (2008). Mapping QTL for climbing ability and component traits in common bean. Molecular Breeding, 22, 201-215.

Cichy, K. A., Blair, M. W., Galeano Mendoza, C. H., Snapp, S. S., \& Kelly, J. D. (2009). QTL analysis of root architecture traits and low phosphorus tolerance in an Andean bean population. Crop Science, 49, 59-68.

Del Río, L. E., Venette, J. R., \& Lamey, H. A. (2004). Impact of white mold incidence on dry bean yield under nonirrigated conditions. Plant Disease, 88, 1352-1356.

Eckert, F. R., Kandel, H. J., Johnson, B. L., Rojas-Cifuentes, G. A., Deplazes, C., Vander Wal, A. J., et al. (2011). Row spacing and nitrogen effects on upright pinto bean cultivars under direct harvest conditions. Agronomy Journal, 103, 1314-1320.

Ender, M., \& Kelly, J. D. (2005). Identification of QTL associated with white mold resistance in common bean. Crop Science, 45, 2482-2490.

Freyre, R., Skroch, P., Geffroy, V., Adam-Blondon, A. F., Shirmohamadali, A., Johnson, W., et al. (1998). Towards an integrated linkage map of common bean. 4. Development of a core map and alignment of RFLP maps. Theoretical and Applied Genetics, 97, 847-856.

Hang, A. N., Miklas, P. N., Silbernagel, M. J., \& Hosfield, G. L. (2006). Registration of 'Quincy' pinto bean. Crop Science, 46, 991.

Harikrishnan, R., \& Del Río, L. E. (2006). Influence of temperature, relative humidity, ascospore concentration, and length of drying of colonized dry bean flowers on white mold development. Plant Disease, 90, 946-950.

Hosfield, G. L., \& Hang, A. N. (2005). Registration of 'Claret' small red bean. Crop Science, 45, 1663-1664.

Jones, S. J., Gent, D. H., Pethybridge, S. J., \& Hay, F. S. (2011). Spatial characteristics of white mould epidemics and the development of sequential sampling plans in Australian bean fields. Plant Pathology, 60, 1169-1182.

Kelly, J. D. (2001). Remaking bean plant architecture for efficient production. Advances in Agronomy, 71, 109-143.

Kelly, J. D., Hosfield, G. L., Varner, G. V., Uebersax, M. A., \& Taylor, J. (1999). Registration of 'Matterhorn' great northern bean. Crop Science, 39, 589-599.

Kelly, J. D., Varner, G. V., Mkwaila, W., Cichy, K. A., \& Wright, E. M. (2012). Registration of 'Eldorado' pinto bean. Journal of Plant Registrations, 6, 233-237.
Kolkman, J. M., \& Kelly, J. D. (2000). An indirect test using oxalate to determine physiological resistance to white mold in common bean. Crop Science, 40, 281-285.

Kolkman, J. M., \& Kelly, J. D. (2002). Agronomic traits affecting resistance to white mold in common bean. Crop Science, 42, 693-699.

Kolkman, J. M., \& Kelly, J. D. (2003). QTL conferring resistance and avoidance to white mold in common bean. Crop Science, 43, 539-548.

Kwak, M., Velasco, D., \& Gepts, P. (2008). Mapping homologous sequences for determinacy and photoperiod sensitivity in common bean (Phaseolus vulgaris). Journal of Heredity, 99, 283-291.

Maxwell, J. J., Brick, M. A., Byrne, P. F., Schwartz, H. F., Shan, X., Ogg, J. B., et al. (2007). Quantitative trait loci linked to white mold resistance in common bean. Crop Science, 47, 2285-2294.

McCoy, S., Higgens, B., \& Steadman, J. R. (2012). Use of multi site screening to identify and verify partial resistance to white mold in common bean in 2011. Annual Report Bean Improvement Cooperative, 55, 153-154.

Miklas, P. N. (2007). Marker-assisted backcrossing QTL for partial resistance to Sclerotinia white mold in dry bean. Crop Science, 47, 935-942.

Miklas, PN (2010) National cooperative dry bean nursery, 61st annual report. Retrieved Nov 27, 2012 from http://www.ars.usda.gov/SP2UserFiles/person/3848/ PDF/Miklas_2011/2010cdbnreport\%20final.pdf

Miklas, P. N., \& Grafton, K. F. (1992). Inheritance of partial resistance to white mold in inbred populations of dry bean. Crop Science, 32, 943-948.

Miklas, P. N., \& Porch, T. (2010). Guidelines for common bean QTL nomenclature. Annual Report of the Bean Improvement Cooperative, 53, 202-204.

Miklas, P. N., Grafton, K. F., Secor, G. A., \& McClean, P. (1992). Use of pathogen filtrate to differentiate physiological resistance of dry bean to white mold disease. Crop Science, 32, 310-312.

Miklas, P. N., Johnson, W. C., Delorme, R., \& Gepts, P. (2001). QTL conditioning physiological resistance and avoidance to white mold in dry bean. Crop Science, 41, 309-315.

Miklas, P. N., Delorme, R., \& Riley, R. (2003). Identification of QTL conditioning resistance to white mold in snap bean. Journal of the American Society for Horticultural Science, $128,564-570$.

Miklas, P. N., Grafton, K. F., Hauf, D., \& Kelly, J. D. (2006). Registration of partial white mold resistant pinto bean germplasm line USPT-WM-1. Crop Science, 46, 2339.

Miklas, P. N., Larsen, K. M., Terpstra, K., Hauf, D. C., Grafton, K. F., \& Kelly, J. D. (2007). QTL analysis of ICA Bunsiderived resistance to white mold in a pinto $\mathrm{x}$ navy bean cross. Crop Science, 47, 174-179.

Miklas, P. N., Kelly, J. D., Steadman, J. R., \& McCoy, S. (2012). Release of partial white mold resistance pinto USPT-WM12. Annual Report of the Bean Improvement Cooperative, 55, 291-292.

Mkwaila, W., \& Kelly, J. D. (2012). Identification and validation of QTL for resistance to white mold in two pinto bean RIL populations. Annual Report of the Bean Improvement Cooperative, 55, 157-158. 
Mkwaila, W., Terpstra, K. A., Ender, M., \& Kelly, J. D. (2011). Identification of QTL for resistance to white mold in wild and landrace germplasm of common bean. Plant Breeding, $130,665-672$.

Nuland, D., Schild, J., \& Anderson, F. (1989). The effect of added nitrogen on biomass and the incidence of white mold from two on-farm research trials. 1988. Annual Report of the Bean Improvement Cooperative, 32, 109-110.

Osorno, J. M., Grafton, K. F., Rojas-Cifuentes, G. A., Gelin, R., \& Vander Wal, A. J. (2010). Registration of 'Lariat' and 'Stampede' pinto beans. Journal of Plant Registrations, 4, 5-11.

Park, S. J. (1993). Response of bush and upright plant type selections to white mold and seed yield of common beans grown in various row widths in southern Ontario. Canadian Journal of Plant Science, 73, 265-272.

Park, S. O., Coyne, D. P., Steadman, J. R., \& Skroch, P. W. (2001). Mapping of QTL for resistance to white mold disease in common bean. Crop Science, 41, 1253-1262.

Paula Júnior, T. J., Vieira, R. F., Rocha, P. R. R., Bernardes, A., Costa, E. L., Carneiro, J. E. S., et al. (2009). White mold intensity on common bean in response to plant density, irrigation frequency, grass mulching, Trichoderma spp., and fungicide. Summa Phytopathologica, 35, 44-48.

Peachey, E., Ludy, R. L., Powelson, M. L., \& McGrath, D. M. (2006). Modification of plant arrangement suppresses white mold of snap beans. HortScience, 41, 1298-1302.

Pérez-Vega, E., Pascual, A., Campa, A., Giraldez, R., Miklas, P. N., \& Ferreira, J. J. (2012). Mapping QTL conferring partial physiological resistance to white mold in the common bean RIL population Xana/Cornell 49242. Molecular Breeding, 29, 31-41.

Petzoldt, R., \& Dickson, M. H. (1996). Straw test for resistance to white mold in beans. Annual Report Bean Improvement Cooperative, 39, 142-143.

Phillips, A. J. L. (1994). Influence of fluctuating temperatures and interrupted periods of plant-surface wetness on infection of bean leaves by ascospores of Sclerotinia sclerotiorum. Annals of Applied Biology, 124, 413-427.

Purdy, L. H. (1979). Sclerotinia sclerotiorum: history, diseases and symptomatology, host range, geographic distribution and impact. Phytopathology, 69, 875-880.

Schwartz, H. F., \& Steadman, J. R. (1978). Factors affecting sclerotium populations of, and apothecium production by, Sclerotinia sclerotiorum. Phytopathology, 68, 383-388.

Schwartz, H. F., \& Steadman, J. R. (1989). White mold. In H. F. Schwartz \& M. A. Pastor-Corrales (Eds.), Bean production problems in the tropics (pp. 211-230). Cali, Colombia: Centro Internacional de Agricultura Tropical.

Schwartz, H. F., Steadman, J. R., \& Coyne, D. P. (1978). Influence of Phaseolus vulgaris blossoming characteristics and canopy structure upon reaction to Sclerotinia sclerotiorum. Phytopathology, 68, 465-470.

Schwartz, H. F., Casciano, D. H., Asenga, J. A., \& Wood, D. R. (1987). Field measurement of white mold effects upon dry beans with genetic resistance or upright plant architecture. Crop Science, 27, 699-702.

Singh, S. P. (1982). A key for identification of different growth habits of Phaseolus vulgaris L. Annual Report of the Bean Improvement Cooperative, 25, 92-95.

Singh, S. P., \& Schwartz, H. F. (2010). Breeding common bean for resistance to diseases: a review. Crop Science, 50, 2199-2223.

Soule, M., Porter, L., Medina, J., Santana, G. P., Blair, M. W., \& Miklas, P. N. (2011). Comparative QTL map for white mold resistance in common bean, and characterization of partial resistance in dry bean lines VA19 and 19365-31. Crop Science, 51, 123-139.

Steadman, J. R. (1979). Control of white mold disease (Sclerotinia sclerotiorum) of dry edible bean by fungicide applications. Annual Report of the Bean Improvement Cooperative, 22, 31-32.

Tar'an, B., Michaels, T. E., \& Pauls, K. P. (2002). Genetic mapping of agronomic traits in common bean. Crop Science, 42, 544-556.

Terán, H., \& Singh, S. P. (2009). Gamete selection for improving physiological resistance to white mold in common bean. Euphytica, 167, 271-280.

Terán, H., \& Singh, S. P. (2010). Gamete and recurrent selection for improving physiological resistance to white mold in common bean. Canadian Journal of Plant Science, 90, $153-162$.

Terán, H., Lema, M., Schwartz, H. F., Duncan, R., Gilbertson, R., \& Singh, S. P. (2006). Modified Petzoldt and Dickson scale for white mold rating of common bean. Annual Report of the Bean Improvement Cooperative, 49, 115-116.

Vieira, R. F., Paula Júnior, T. J., Teixeira, H., \& Carneiro, J. E. D. S. (2010). White mold management in common bean by increasing within-row distance between plants. Plant Disease, 94, 361-367.

Weiss, A., Kerr, E. D., \& Steadman, J. R. (1980). Temperature and moisture influences on development of white mold disease (Sclerotinia sclerotiorum) on Great Northern beans. Plant Disease, 64, 757-759. 